\title{
Seeds Quality and Quantity of Soybean [Glycine max (L.) Merr.] Cultivars in Response to Cold Stress
}

\author{
Mariola Staniak $^{1, * \mathbb{C}}$, Anna Stępień-Warda ${ }^{1} \mathbb{D}$, Katarzyna Czopek $^{1}$, Anna Kocira ${ }^{2} \mathbb{D}$ and Edyta Baca ${ }^{3}$ \\ 1 Department of Forage Crop Production, Institute of Soil Science and Plant Cultivation-State Research Institute, \\ Czartoryskich 8, 24-100 Puławy, Poland; astepien@iung.pulawy.pl (A.S.-W.); kczopek@iung.pulawy.pl (K.C.) \\ 2 Institute of Agricultural Sciences, State School of Higher Education in Chełm, Pocztowa 54, \\ 22-100 Chełm, Poland; akocira@pwsz.chelm.pl \\ 3 The Lublin Agricultural Advisory Centre in Końskowola, Pożowska 8, 24-130 Końskowola, Poland; \\ ebaca@wodr.konskowola.pl \\ * Correspondence: staniakm@iung.pulawy.pl
}

Citation: Staniak, M.; Stępień-Warda,

A.; Czopek, K.; Kocira, A.; Baca, E.

Seeds Quality and Quantity of

Soybean [Glycine max (L.) Merr.]

Cultivars in Response to Cold Stress.

Agronomy 2021, 11, 520. https://

doi.org/10.3390/agronomy11030520

Academic Editor: Hamid Khazaei

Received: 29 January 2021

Accepted: 8 March 2021

Published: 10 March 2021

Publisher's Note: MDPI stays neutral with regard to jurisdictional claims in published maps and institutional affiliations.

Copyright: (c) 2021 by the authors. Licensee MDPI, Basel, Switzerland. This article is an open access article distributed under the terms and conditions of the Creative Commons Attribution (CC BY) license (https:// creativecommons.org/licenses/by/ $4.0 /)$.

\begin{abstract}
The aim of the study was to identify the response to cold stress of 16 soybean cultivars by evaluating their emergence, yield level, and seed chemical composition. Studies were conducted in 2018-2019. A total of sixteen soybean cultivars belonging to three earliness groups (early, mediumearly and late) were included. Short-term (3-day) cold stress $\left(12 / 6{ }^{\circ} \mathrm{C}\right.$ day/night) was applied immediately after sowing (A), 3 days (B) and 6 days (C) after sowing seeds, while long (9-day) cold stress (D) was applied immediately after sowing seeds. In the control plot (K), plants were grown under optimum conditions $\left(20 / 15{ }^{\circ} \mathrm{C}\right.$ day /night). The study showed that cold stress, reduced plant emergence by $5-10 \%$, depending on the treatment. Long stress (D) had a beneficial effect on the yield of all soybean cultivars (average yield increase of $21.5 \%$ ), with statistically significant differences in 12 cultivars and a trend in four cultivars. Short stress also caused a significant increase in yield on treatments B and C (by 6.8 and $11.6 \%$, respectively). Cold stress did not significantly affect the nutrient content of seed yield. Varietal differentiation was found with respect to yield and chemical composition of seeds.
\end{abstract}

Keywords: chemical composition; cold stress; seeds yield; soybean

\section{Introduction}

Soya is one of the most valuable crops in the world. The seeds contain about $40 \%$ protein with a beneficial amino acid composition and about $20 \%$ fat, half of which is unsaturated fatty acids that lower blood cholesterol levels. They are also a source of many valuable compounds such as fibre, lecithin, vitamins, mineral salts and antioxidants [1]. They are therefore a valuable raw material for the food (oil) and feed (extracted meal) industries. Soybean covers about $29 \%$ of the world supply of consumer vegetable oil [2]. In many countries soybeans are used as a meat substitute, because soy protein contains a set of amino acids in proportions similar to the reference protein (chicken egg) [3]. Soy is also used in the pharmaceutical and chemical industries [4,5]. In addition, oil is one of the basic raw materials for biodiesel production [6]. Soybean, as a species of the Legume family, brings additional economic and ecological benefits due to nitrogen fixation by the bacteria Bradyrhizobium japonicum. As a result, it has low requirements for mineral fertilization and additionally increases the yield of successive plants, e.g., cereals $[7,8]$. Thanks to its versatile use, it currently occupies the largest sown area of legumes in the world (in 2018, over 125 million hectares) [9].

Attempts to introduce thermophilic species such as soybean into cultivation in Poland are connected, among others, with the warming of the climate observed in recent years and the lengthening of the growing season in Poland's latitude [10]. Soybean is a short-day plant with high temperature requirements, especially during the flowering stage [11-13]. 
According to Cai et al [14], photoperiod and temperature are the most important factors affecting the growth and development of soybean, while at the same time severely limiting the cultivation range of this species. Soybean is sensitive to thermal conditions throughout its life cycle, i.e., from emergence to maturity. Câmara et al [11] state that during the growing season, the average daily temperature should not be lower than $15^{\circ} \mathrm{C}$, as low temperatures slow down the growth of the plants, prevent the production of new leaves, shoots and pods. A drop in temperature below $10^{\circ} \mathrm{C}$ may even prevent the soybean from flowering. According to Gass et al [12], the flowering stage is a critical period associated with a particular sensitivity to low temperatures, where a temperature range of 17 to $18^{\circ} \mathrm{C}$ is considered the biological minimum, while $22-25^{\circ} \mathrm{C}$ is the optimum. Soybean has lower heat requirements during the maturing period, at the biological minimum of 8 to $14{ }^{\circ} \mathrm{C}$, with an optimum of 14 to $19{ }^{\circ} \mathrm{C}$. In the study of Ohnishi et al [15], low temperatures $\left(15 / 10^{\circ} \mathrm{C}\right.$ day/night) at $3-4$ days before anthesis of soybean, affected the fertilization process and consequently, decreased pod setting and seed yield. There is little research on the response of soybean to low temperatures at earlier developmental stages. Łykowski [16] states, that temperature $10{ }^{\circ} \mathrm{C}$ is the lowest that still ensures normal soybean vegetation.

Research on the effects of stress factors on crops has been carried out for several decades in many centers in Poland and abroad. This is based on breeding methods aimed at consolidating favorable plant traits, especially productivity and resistance to stress factors [17]. Advanced research is also being conducted on genes related to soybean's response to low temperatures. Zhang et al [18] showed that thermal response was controlled by three pairs of major genes and the heritability was as high as $92.66 \%$. However, the complexity of the problem lies in the fact that not only genetic, but also environmental factors determine the sensitivity of plants to stress. Stress factors can disrupt bioenergetic processes, alter plant metabolism, cause damage to cell structures and, as a consequence, inhibit plant growth, reduce yield, and deteriorate plant quality [19]. Therefore, understanding the mechanism of photothermal sensitivity in soybean can provide a theoretical basis for improving cultivars. Under natural conditions, plants usually acquire low temperature tolerance through acclimatization to cold, i.e., gradual exposure to low, non-freezing temperatures [20]. This process is linked to multiple mechanisms that include changes in gene expression, cell membrane structure, abscisic acid elevation, or accumulation of water-soluble sugars [21,22]. Unfavorable growing conditions restrict the fundamental processes of growth and development of soybean and consequently cause a reduction in yield and its nutritional value [23].

Varietal variation in soybean in response to cold stress has been reported by many authors. Kołodziej and Pisulewska [24] found, that of the two soybean cultivars tested, Naviko was more sensitive to adverse weather conditions than Aldana, and an increase in temperature amplitude contributed to an increase in seed and fat yields in both varieties. Gass et al [12] showed variation among 10 soybean genotypes in cold tolerance by $3{ }^{\circ} \mathrm{C}$ between tolerant and susceptible genotypes in the threshold, below which temperatures can be considered to be damaging during flowering $\left(15\right.$ and $\left.18{ }^{\circ} \mathrm{C}\right)$. Zhang et al [18] report that, along with the release years of soybean cultivars in China, the vegetation period was shortened, the reproductive period was prolonged, and the sensitivity to photoperiod was lower in new cultivars than in old ones. The long-term genetic breeding improved the photo-thermal adaptability, yield, agronomic and quality traits of soybean.

Agriculture is one of the economic branches that is most dependent on weather and climate conditions. Counteracting stress is, therefore, one of the main ways of ensuring yield stability in crop production. According to Anioł et al [25], the difference between the potential yield of currently cultivated crops in Poland and the real yield may reach as much as $70 \%$; therefore, from the cognitive and economic point of view, any research aimed at elucidating the basis of plant resistance to stresses is highly desirable. The aim of this study was to identify the response to cold stress applied at very early developmental stages of 16 soybean cultivars by evaluating emergence, yield, and chemical composition of seeds. 


\section{Materials and Methods}

\subsection{Plants and Growth Conditions}

The experiment was carried out twice, in 2018 and 2019, under controlled conditions (phytotrons) and partially controlled conditions (greenhouse) belonging to the Institute of Soil Science and Plant Cultivation-State Research Institute in Puławy, Poland (51 $24^{\prime} 59^{\prime \prime} \mathrm{N}$, $21^{\circ} 58^{\prime} 09^{\prime \prime}$ E). The research subjects were 16 cultivars of soybean Glycine max (L.) Merr., belonging to 3 earliness groups: very early and early cultivars (EC): Aldana (breeder PL; year of registration in Poland 1992), Annushka (UA; 2019), Augusta (PL; 2020), Erica (PL; 2017), Oressa (BY; 2018), Paradis (CH; 2017); semi-late cultivars (SC): Abelina (AT; 2016), Maja (PL; 2017), Mavka (PL; 2013), Merlin (AT; not registered in Poland), Sculptor (DE; 2017), and late and very late cultivars (LC): Aligator (FR; 2015), GL Melanie (AT; 2017), Lissabon (AT; not registered in Poland, Madlen (PL; 2015), Petrina (CA; 2017). All cultivars are listed in the EU Common Catalogue [26]. The experiments were conducted using the complete randomization method in 3 replications. Soybean seeds were treated with an antifungal dressing SAROX 75 WS two days before sowing, and on the day of sowing they were inoculated with a bacterial culture Nitragina containing strains Bradyrhizobium japonicum. The seeds were sown on 4th and 6th May into multiplats (6 little pots $\times 3$ seeds $\times 3$ multiplats per cultivar) filled with universal soil substrate for vegetables and placed in MICRO-CLIMA phytotrons from SNIJDERS LABS. In the first phytotron, the air temperature was $12 / 6^{\circ} \mathrm{C}$ day/night as stress conditions, while in the second phytotron, the air temperature was $20 / 15^{\circ} \mathrm{C}$ day/night as optimal conditions. In both phytotrons, humidity was $50 \%$, photoperiod $16 / 8 \mathrm{~h}$ day/night. Short-term cold stress (3 days) was applied at different periods of initial soybean growth, i.e., immediately after sowing (regime A), after 3 days (B) and after 6 days (C) from seed sowing. On the fourth treatment (D), a long cold stress (9 days) was applied immediately after sowing the seeds. In the control treatment $(\mathrm{K})$, the plants were in optimal conditions all the time. Watering was done as needed to ensure optimal conditions for plant growth and development.

After the seedlings were in a phase when the first pair of true leaves developed (BBCH 11), the plants were transplanted into Mitcherlich pots with $7 \mathrm{~kg}$ of light silty loam (5 plants per pot), which were then placed in a greenhouse for further growth and development. The soil for the pots, coming from the arable layer of the field, after the cereal forecrop (seasoned for 10 months), was mixed with sand in a ratio of 5:2. It had the following content of available mineral components ( $\mathrm{g} 100 \mathrm{~g}^{-1}$ soil): $\mathrm{P}-13.8-32.7$, $\mathrm{K}-12.2-20.6, \mathrm{Mg}-8.8-11.0, \mathrm{~S}-0.53-1.34$ and micronutrients ( $\mathrm{mg} \mathrm{kg}^{-1}$ soil): $\mathrm{Cu}-7.6-10.5$, $\mathrm{Zn}-24.1-30.2, \mathrm{Mn}-206-213, \mathrm{~B}-7.2-10.5, \mathrm{Mb}<0.2$. The content of $\mathrm{C}_{\text {org }}$ was $0.87-1.03 \%$, while soil $\mathrm{pH}_{\mathrm{KCl}}$ 6.3-6.7. The plants were fertilized before sowing with $\left(\mathrm{g} \mathrm{pot}^{-1}\right): \mathrm{N}$ in the form of $\mathrm{NH}_{4} \mathrm{NO}_{3}-0.5, \mathrm{P}$ in the form of $\mathrm{KH}_{2} \mathrm{PO}_{4}-1.01, \mathrm{~K}$ in the form of $\mathrm{K}_{2} \mathrm{SO}_{4}-1.50, \mathrm{Mg}$ in the form of $\mathrm{MgSO}_{4}-0.5$ and micronutrient solution. The pots were placed on trolleys, so they were pulled into the greenhouse at night and during the rain. During the day, the pots were placed in the open air, so that the thermal conditions were as close to natural as possible, and watering was optimal. Mean temperature during flowering (June) was $18.4{ }^{\circ} \mathrm{C}$ in 2018 and $21.7^{\circ} \mathrm{C}$ in 2019 . The temperature at night never dropped below $10^{\circ} \mathrm{C}$. Harvesting dates were different, as the cultivars belonged to 3 groups of earliness. The EC group was harvested from the end of August to September, the SC group in September, and LC group from the end of September to October. Each variety was harvested individually, when it reached harvest maturity (seed moisture at harvest ranging between 8 and 12\%).

\subsection{Methods and Measurements}

Plant emergence 10 and 21 days after sowing (as the ratio of emerged plants to all seeds sown) was determined, seed yield (seed weight per pot) was weighed, and chemical analyses of the seeds in the Certified Chemical Laboratory in Puławy were performed. The contents of basic nutrients were analyzed separately for each year as a collective sample for the object. The contents of N by Kjeldahl's method [27], crude fat (CFa) by Soxhlet's method [28], water soluble carbohydrates (WSC) by Bertrand's method [29], crude fibre 
(CF) by enzymatic-weight method [30], and crude ash (CA) by conventional methods (dry mineralization) [30] were determined, based on the average for treatments. The total protein $(\mathrm{CP})$ content was calculated with the formula $\mathrm{CP}=\mathrm{N} \times 5.71$ [31].

\subsection{Statistical Analysis}

The results of the research on seed yield were statistically analyzed for a 2-factor experiment by the analysis of variance method, determining half confidence intervals with the Tukey test at the significance level of $p=0.05$, using the STATGRAPH Plus for Windows v. 4.1 program. Analysis of variation (ANOVA) for seeds yield was done as mean for 2018 and 2019, where regime of cold stress and cultivars were the factors of the experiment ( 5 stress regimes $\times 16$ cultivars $\times 3$ replications - an independent pot as a replication). Tukey's multiple comparison test was used to compare differences between the means for main factors (stress regime $\mathrm{S}$ and variety V), and for subclasses (interaction $\mathrm{S} \times \mathrm{V}$ ). Seed nutrient content as mean for 2018 and 2019, was developed by analysis of variance for a 2-factor experiment in one replication (collective sample for the object), determining half confidence intervals with the Tukey's test at a significance level of $p=0.05$, where the interaction was treated as an error, using the ANWA-BP for Windows software.

\section{Results}

\subsection{Plant Emergency}

At the first date (10 days after seed sowing of soybean), the most numerous plant emergence was recorded on the control treatment $(\mathrm{K})$, with an average of $83 \%$, while after a short 3-day cold stress (A, B, C), emergence was weaker and at a similar level, with an average of $70 \%$. Soybean emergence was not observed under long 9-day cold stress (D) (Table 1). At 3 weeks after seed sowing, emergence averaged $90 \%$ on the control object (K) and 80 to $85 \%$ on the other sites (A-D) (Table 2). Varietal variation in soybean emergence was also found. Under control conditions (K), the highest emergence was recorded for: Augusta, Aldana, Erica, Paradis, Maja and Petrina (above 95\%), while the smallest for Mavka - $61 \%$ and GL Melanie-74\%. Cold stress reduced the emergence of Mavka the most, and at the same time this cultivar being more sensitive to stress inflicted immediately after sowing (A and D-reduction in emergence, by 52 and $48 \%$, respectively) than after plant germination (B and C-reduction in emergence, by 27 and 20\%, respectively) (Table 2). An average 15\% reduction in emergence was also recorded in the cultivar Erica.

Table 1. Seedling emergence (\%) after 10 days depending on stress regime and cultivar $(\mathrm{n}=36)$.

\begin{tabular}{ccccccc}
\hline \multirow{2}{*}{ Cultivar } & $\begin{array}{c}\text { Earliness } \\
\text { Group }\end{array}$ & \multicolumn{5}{c}{ Stress Regime } \\
\cline { 3 - 7 } & & K & A & B & C & D \\
\hline Augusta & EC & 94.4 & 95.8 & 93.1 & 88.9 & 0.0 \\
Annushka & EC & 83.3 & 65.3 & 62.5 & 62.5 & 0.0 \\
Aldana & EC & 94.4 & 88.9 & 83.3 & 79.2 & 0.0 \\
Erica & EC & 73.6 & 65.3 & 66.7 & 66.7 & 0.0 \\
Paradis & EC & 93.1 & 88.9 & 94.4 & 91.7 & 0.0 \\
Oressa & EC & 84.7 & 62.5 & 75.0 & 62.5 & 0.0 \\
Merlin & SC & 91.7 & 75.0 & 76.4 & 84.7 & 0.0 \\
Lissabon & LC & 80.6 & 66.7 & 76.4 & 76.4 & 0.0 \\
Abelina & SC & 83.3 & 69.4 & 72.2 & 72.2 & 0.0 \\
Maja & SC & 93.1 & 77.8 & 72.2 & 79.2 & 0.0 \\
Mavka & SC & 47.2 & 13.9 & 16.7 & 18.1 & 0.0 \\
Sculptor & SC & 70.8 & 59.7 & 55.6 & 68.1 & 0.0 \\
Aligator & LC & 86.1 & 73.6 & 77.8 & 70.8 & 0.0 \\
GL & LC & 62.5 & 45.8 & 52.8 & 45.8 & 0.0 \\
Melanie & LC & 88.9 & 76.4 & 72.2 & 81.9 & 0.0 \\
Madlen & LC & 93.1 & 88.9 & 79.2 & 79.2 & 0.0 \\
Petrina & Average & 62.6 & 69.6 & 70.4 & 70.5 & 0.0 \\
\hline \multicolumn{7}{c}{ K-control object; A-short stress after sowing; B-short stress after 3 days after sowing; C-short stress after 6 } \\
days after sowing; D-long stress after sowing. & & & &
\end{tabular}


Table 2. Seedling emergence (\%) after 21 days depending on stress regime and cultivar $(\mathrm{n}=36)$.

\begin{tabular}{|c|c|c|c|c|c|c|}
\hline \multirow{2}{*}{ Cultivar } & \multirow{2}{*}{$\begin{array}{c}\text { Earliness } \\
\text { Group }\end{array}$} & \multicolumn{5}{|c|}{ Stress Regime } \\
\hline & & $\mathbf{K}$ & A & B & $\mathrm{C}$ & D \\
\hline Augusta & $\mathrm{EC}$ & 95.8 & 97.2 & 97.2 & 95.8 & 95.8 \\
\hline Annushka & $\mathrm{EC}$ & 88.9 & 72.2 & 70.8 & 77.8 & 83.3 \\
\hline Aldana & $\mathrm{EC}$ & 97.2 & 95.8 & 95.8 & 91.7 & 91.7 \\
\hline Erica & $\mathrm{EC}$ & 97.2 & 84.7 & 86.1 & 77.8 & 79.2 \\
\hline Paradis & $\mathrm{EC}$ & 95.8 & 94.4 & 97.2 & 97.2 & 98.6 \\
\hline Oressa & $\mathrm{EC}$ & 93.1 & 72.2 & 84.7 & 75.0 & 87.5 \\
\hline Merlin & SC & 94.4 & 86.1 & 90.3 & 94.4 & 95.8 \\
\hline Lissabon & LC & 91.7 & 80.6 & 91.7 & 87.5 & 90.3 \\
\hline Abelina & SC & 93.1 & 88.9 & 93.1 & 87.5 & 90.3 \\
\hline Maja & SC & 95.8 & 86.1 & 80.6 & 91.7 & 90.3 \\
\hline Mavka & SC & 61.1 & 29.2 & 44.4 & 48.6 & 31.9 \\
\hline Sculptor & SC & 84.7 & 70.8 & 70.8 & 79.2 & 80.6 \\
\hline Aligator & $\mathrm{LC}$ & 88.9 & 90.3 & 91.7 & 86.1 & 97.2 \\
\hline $\begin{array}{c}\text { GL } \\
\text { Melanie }\end{array}$ & LC & 73.6 & 62.5 & 66.7 & 65.3 & 68.1 \\
\hline Madlen & LC & 90.3 & 86.1 & 83.3 & 97.2 & 90.3 \\
\hline Petrina & $\mathrm{LC}$ & 95.8 & 88.9 & 87.5 & 91.7 & 86.1 \\
\hline \multicolumn{2}{|c|}{ Average } & 89.8 & 80.4 & 83.2 & 84.0 & 84.8 \\
\hline
\end{tabular}

K-control object; A-short stress after sowing; B-short stress after 3 days after sowing; C-short stress after 6 days after sowing; D-long stress after sowing.

\subsection{Seed Yield}

Stress regime and genetic factor (cultivar) significantly affected soybean yield (Appendix A). Regardless of cultivar, the lowest seed yield was obtained in the control object (K) and after application of a short 3-day stress immediately after sowing (A). Short stress applied at later developmental stages $(B, C)$ resulted in a significant increase in yield by 6.8 and $11.6 \%$, respectively, compared to the control. However, the highest seed yield was obtained after a long, 9-day cold stress (D), on average $21.5 \%$ higher than the control treatment (Figure 1). Considering cultivar earliness groups, the highest increase in seed yield after a long stress was shown in early and very early cultivars (EC) - by $27.3 \%$ on average, while a slightly smaller increase was shown in semi-late cultivars (SC) as well as late and very late cultivars (LC) - by $19.7 \%$ on average.

Regardless of stress regime, the lowest seed yield was obtained from Madlen and Annushka cultivars, 25.9 and $26.9 \mathrm{~g} \mathrm{pot}^{-1}$, respectively, while all other cultivars yielded significantly higher. The highest seed yield was obtained from Abelina, GL Melanie and Petrina cultivars, 45.9, 45.2 and $44.9 \mathrm{~g} \mathrm{pot}^{-1}$, respectively. Considering the earliness groups, the lowest yielding cultivars were the early ones (EC)—on average $32.5 \mathrm{~g} \mathrm{pot}^{-1}$, mediumyielding were semi-late cultivars (SC)—on average $39.0 \mathrm{~g} \mathrm{pot}^{-1}$, while the highest-late cultivars (LC)-39.8 $\mathrm{g} \mathrm{pot}^{-1}$. In the EC group, Erica stood out favorably in terms of yield, in the SC group-Abelina, while in the LC group-Petrina and GL Melanie. On the other hand, the weakest were: in the EC group-Annushka, in the SC group-Maja, and in the LC group-Madlen (Figure 2). Statistical analysis of the test results confirmed the significant interaction of the cultivar with the stress regime. Short cold stress applied 3 days after sowing (B) contributed to significant increase in seed yield in Madlen and Oressa cultivars, while that applied 6 days after sowing $(\mathrm{C})$ - in Oressa and Lissabon cultivars compared to the control object (K). On the other hand, a long, 9-day cold stress contributed to a significant increase in soybean seed yield in almost all cultivars except Paradis, Oressa, Merlin and Lissabon, in which such a trend was recorded (Table 3). 


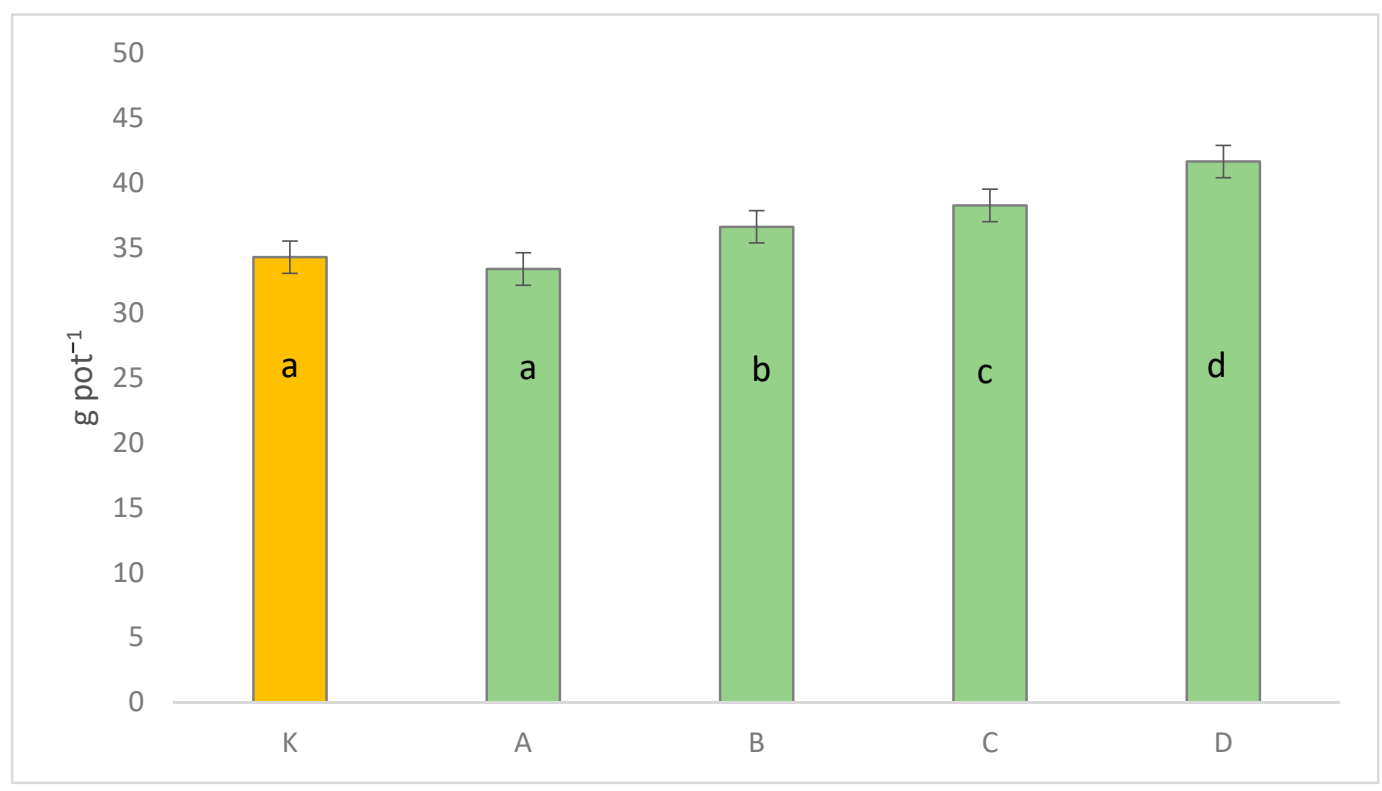

Figure 1. Yield of soybean seeds depending on stress regime $(\mathrm{n}=96) ; \pm \operatorname{LSD}(p \leq 0.05)$; different lower case means significant differences in the Tukey test; $\mathrm{K}$ - control object; $\mathrm{A}$ —short stress after sowing; $\mathrm{B}$ — short stress after 3 days after sowing; $\mathrm{C}$ - short stress after 6 days after sowing; D—long stress after sowing.

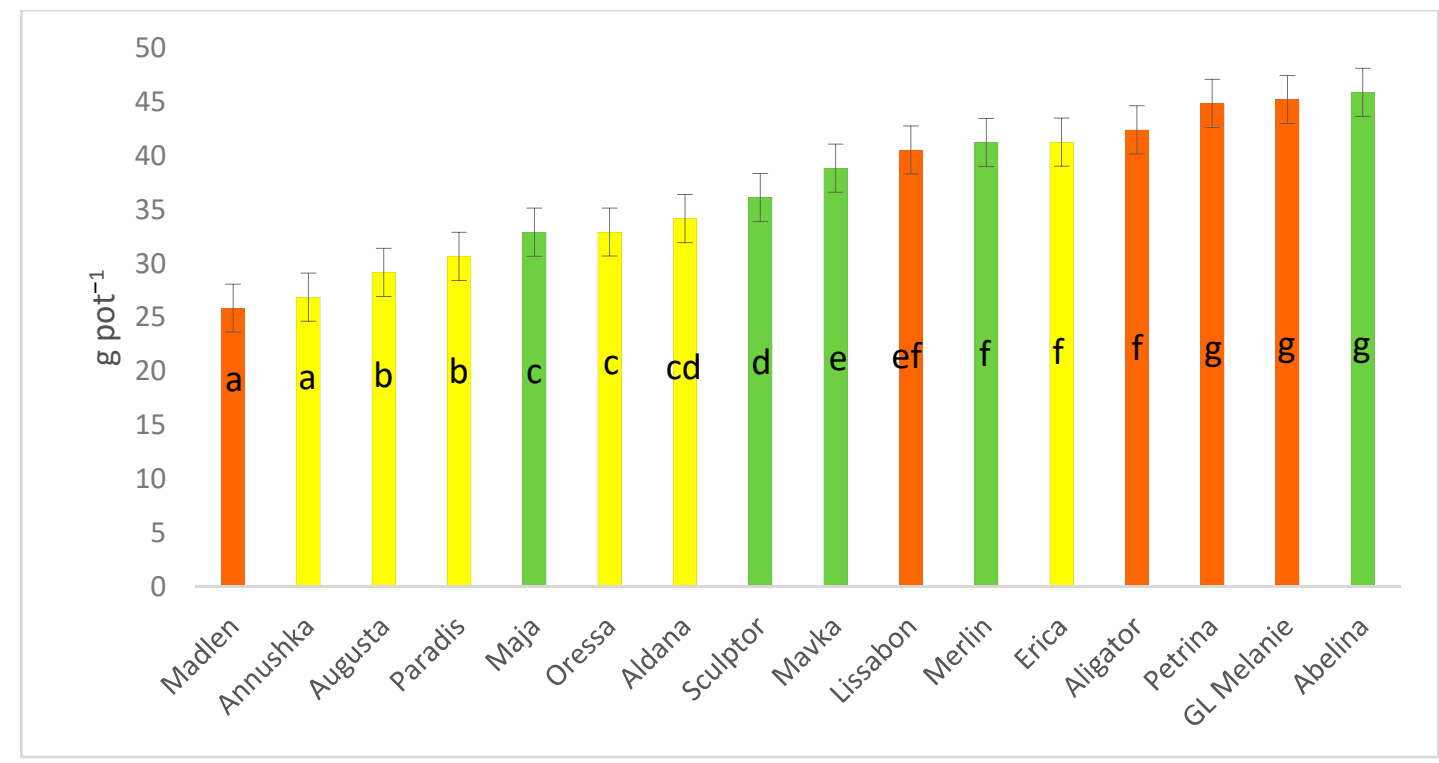

Figure 2. Yield of soybean seeds depending on the cultivar $(\mathrm{n}=30) ; \pm \operatorname{LSD}(p \leq 0.05)$; different letters mean significant differences in the Tukey test; yellow bars-group of very early and early cultivars (EC); green bars-group of semi-late cultivars (SC); orange bars-group of late and very late cultivars (LC). 
Table 3. Yield of soybean seeds depending on cultivar and stress regime (interaction). \pm SD $(n=6)$.

\begin{tabular}{ccccccc}
\hline \multirow{2}{*}{$\begin{array}{c}\text { Cultivar } \\
\text { (II) }\end{array}$} & $\begin{array}{c}\text { Earliness } \\
\text { Group }\end{array}$ & \multicolumn{5}{c}{ Regime Stress (I) } \\
\cline { 3 - 7 } & & K & A & B & C & D \\
\hline Madlen & LC & $20.7 \pm 1.4$ & $25.3 \pm 2.8$ & $30.3 \pm 1.9 *$ & $25.3 \pm 1.6$ & $27.8 \pm 2.9^{*}$ \\
Annushka & EC & $24.2 \pm 1.2$ & $24.4 \pm 1.6$ & $23.5 \pm 4.2$ & $28.1 \pm 2.4$ & $34.3 \pm 4.0^{*}$ \\
Augusta & EC & $28.2 \pm 1.4$ & $26.7 \pm 3.1$ & $25.4 \pm 3.6$ & $30.4 \pm 4.3$ & $35.2 \pm 2.7^{*}$ \\
Paradis & EC & $27.9 \pm 4.2$ & $28.2 \pm 6.4$ & $30.9 \pm 1.5$ & $33.9 \pm 1.7 *$ & $32.5 \pm 4.7$ \\
Maja & SC & $30.5 \pm 4.2$ & $29.8 \pm 1.4$ & $32.9 \pm 2.1$ & $35.1 \pm 1.3$ & $36.3 \pm 3.8^{*}$ \\
Oressa & EC & $29.6 \pm 2.8$ & $29.0 \pm 6.0$ & $35.4 \pm 5.2 *$ & $36.4 \pm 2.6 *$ & $34.2 \pm 3.4$ \\
Aldana & EC & $30.4 \pm 0.7$ & $32.0 \pm 1.0$ & $33.1 \pm 3.6$ & $33.5 \pm 1.7$ & $41.9 \pm 4.2^{*}$ \\
Sculptor & SC & $33.1 \pm 1.5$ & $32.2 \pm 1.1$ & $37.2 \pm 2.4$ & $37.6 \pm 2.9$ & $40.6 \pm 0.6 *$ \\
Mavka & SC & $36.1 \pm 1.3$ & $36.3 \pm 2.1$ & $36.6 \pm 2.9$ & $38.6 \pm 0.4$ & $46.6 \pm 0.5 *$ \\
Lissabon & LC & $38.0 \pm 1.8$ & $38.8 \pm 2.8$ & $40.5 \pm 1.5$ & $43.5 \pm 3.0 *$ & $42.0 \pm 2.9$ \\
Merlin & SC & $40.8 \pm 1.3$ & $36.1 \pm 3.2$ & $38.7 \pm 1.7$ & $45.1 \pm 3.0$ & $45.5 \pm 4.4$ \\
Erica & EC & $38.0 \pm 0.6$ & $39.4 \pm 0.5$ & $38.7 \pm 4.9$ & $41.8 \pm 2.0$ & $48.4 \pm 3.1 *$ \\
Aligator & LC & $40.1 \pm 1.0$ & $42.4 \pm 1.6$ & $42.0 \pm 4.0$ & $42.2 \pm 6.3$ & $45.5 \pm 3.3 *$ \\
Petrina & LC & $44.6 \pm 2.0$ & $35.8 \pm 0.4$ & $45.9 \pm 4.4$ & $47.3 \pm 1.0$ & $50.9 \pm 3.9 *$ \\
GL & LC & $42.4 \pm 3.0$ & $37.4 \pm 6.1$ & $48.1 \pm 2.6 *$ & $44.8 \pm 3.1$ & $53.5 \pm 4.4^{*}$ \\
Melanie & SC & $43.7 \pm 2.2$ & $40.0 \pm 1.8$ & $46.6 \pm 3.6$ & $48.4 \pm 5.5$ & $50.8 \pm 2.2^{*}$ \\
Abelina & SC & & & I $\times$ II-4.98 & &
\end{tabular}

K-control object; A—short stress after sowing; B-short stress after 3 days after sowing; $\mathrm{C}-$ short stress after 6 days after sowing; D-long stress after sowing; EC—group of very early and early cultivars; SC—group of semi-late cultivars; LC—group of late and very late cultivars; * mean significant differences in relation to the control object in the Tukey test $(p \leq 0.05)$.

\subsection{Chemical Composition of Seeds}

Regardless of the experimental factors, soybean seeds contained an average $384 \mathrm{~g} \mathrm{~kg}^{-1}$ total protein (CP), $215 \mathrm{~g} \mathrm{~kg}^{-1}$ crude fat $(\mathrm{CFa}), 119 \mathrm{~g} \mathrm{~kg}^{-1}$ water-soluble carbohydrates (WSC), $57.5 \mathrm{~g} \mathrm{~kg}^{-1}$ crude fiber (CF), and $52.7 \mathrm{~g} \mathrm{~kg}^{-1}$ crude ash (CA). The nutrient content of soybean seeds depended on the genetic factor, while the stress regime had no significant effect on seed quality. Long cold stress (D) and short stress applied 6 days after sowing to soybean $(\mathrm{C})$ resulted in a slight increase in $\mathrm{CP}$ content $(1.7 \%$ on average) and a decrease in CF content ( $3.1 \%$ on average) and WSC content ( $2.2 \%$ on average), but the differences were not statistically confirmed (Table 4). Long stress (D) also slightly reduced CFa content compared to the other treatments.

Table 4. Chemical composition of soybean seeds $\left(\mathrm{g} \mathrm{kg}^{-1}\right)$, depending on stress regime $(\mathrm{n}=32)$.

\begin{tabular}{cccccc}
\hline $\begin{array}{c}\text { Stress } \\
\text { Regime }\end{array}$ & CP & CFa & WSC & CF & CA \\
\hline K & 380.1 & 214.8 & 119.6 & 58.3 & 53.2 \\
A & 381.8 & 214.2 & 119.2 & 58.6 & 52.8 \\
B & 384.5 & 215.4 & 120.2 & 57.8 & 52.1 \\
C & 386.4 & 215.2 & 116.5 & 56.6 & 52.9 \\
D & 386.7 & 213.9 & 117.4 & 56.4 & 52.5 \\
\hline LSD $(p \leq$ & ns & ns & ns & ns & ns \\
$0.05)$ & & & &
\end{tabular}

K-control object; A-short stress after sowing; B-short stress after 3 days after sowing; C-short stress after 6 days after sowing; $\mathrm{D}$-long stress after sowing; $\mathrm{CP}$-crude protein, $\mathrm{CFa}$-crude fat, WSC-water soluble carbohydrates, $\mathrm{CF}$ - crude fibre, $\mathrm{Ca}$-crude ash.

Varietal differentiation was shown in the content of all studied nutrients (Table 5). Aligator cultivar accumulated the least amount of CP in seeds $\left(348 \mathrm{~g} \mathrm{~kg}^{-1}\right)$, while the remaining cultivars had a significantly higher content of this component. The highest content of $\mathrm{CP}$ was found in the seeds of Maja cultivar $\left(427 \mathrm{~g} \mathrm{~kg}^{-1}\right)$. The content of $\mathrm{CFa}$ 
ranged from 192 to $230 \mathrm{~g} \mathrm{~kg}^{-1}$. Augusta and Madlen accumulated the least amount of this component in seeds, while the other cultivars significantly more. The cultivars most abundant in CFa were: Alligator, Mavka, Lissabon, Petrina, Abelina and Merlin. The genetic factor significantly affected the content of WSC. The least amount was accumulated by GL Melanie (106 $\mathrm{g} \mathrm{kg}^{-1}$ ), while the most-by Oressa and Merlin (respectively, 133 and $132 \mathrm{~g} \mathrm{~kg}^{-1}$ ). The other cultivars accumulated WSC at an average level. CF content ranged from 46 to $68 \mathrm{~g} \mathrm{~kg}^{-1}$, whereas the lowest content of this component was found in Sculptor and Mavka seeds, while the highest-in Merlin cultivar. The lowest content of CA was found in Abelina (48 $\left.\mathrm{g} \mathrm{kg}^{-1}\right)$, while the highest-in Annushka $\left(55 \mathrm{~g} \mathrm{~kg}^{-1}\right)$.

Table 5. Chemical composition of soybean seeds $\left(\mathrm{g} \mathrm{kg}^{-1}\right)$ depending on cultivar $(\mathrm{n}=10)$.

\begin{tabular}{|c|c|c|c|c|c|}
\hline Cultivar (II) & $\mathrm{CP}$ & $\mathrm{CFa}$ & WSC & CF & CA \\
\hline Madlen & 391.3 & 192.2 & 120.3 & 54.4 & 54.0 \\
\hline Annushka & 370.5 & 217.7 & 125.0 & 59.8 & 55.0 \\
\hline Augusta & 402.3 & 192.2 & 108.4 & 63.3 & 54.1 \\
\hline Paradis & 392.6 & 210.0 & 122.0 & 61.8 & 53.3 \\
\hline Maja & 427.1 & 210.6 & 115.3 & 50.5 & 50.9 \\
\hline Oressa & 379.7 & 202.8 & 132.7 & 65.8 & 54.5 \\
\hline Aldana & 380.8 & 208.5 & 124.0 & 56.5 & 54.5 \\
\hline Sculptor & 403.6 & 209.7 & 119.5 & 46.4 & 52.6 \\
\hline Mavka & 372.2 & 229.7 & 123.5 & 47.7 & 52.2 \\
\hline Lissabon & 366.9 & 229.2 & 131.5 & 61.1 & 51.5 \\
\hline Merlin & 377.4 & 225.3 & 113.6 & 68.5 & 50.1 \\
\hline Erica & 399.8 & 206.0 & 112.5 & 61.4 & 53.6 \\
\hline Aligator & 348.4 & 230.1 & 110.7 & 58.7 & 52.7 \\
\hline Petrina & 364.0 & 227.7 & 111.3 & 56.8 & 52.2 \\
\hline GL Melanie & 400.5 & 215.8 & 106.1 & 48.9 & 54.6 \\
\hline Abelina & 365.1 & 227.5 & 121.1 & 59.0 & 47.5 \\
\hline $\begin{array}{c}\mathrm{LSD}(p \leq \\
0.05)\end{array}$ & 10.83 & 5.13 & 6.36 & 6.00 & 1.92 \\
\hline
\end{tabular}

\section{Discussion}

Latitude determines the length of day and temperature, the most important factors to take into account when selecting a region for soybean cultivation. Climatic conditions in Poland are characterized by a relatively cool spring, which is very important from the point of view of the thermal requirements of soybean; hence, sowing is carried out only at the end of April to the beginning of May. The long duration of plant vegetation means, however, that delaying sowing carries a risk of plants not ripening and being harvested before autumn frosts, especially in the case of late cultivars. Therefore, the sowing date is very important, especially in the event of a cool spring.

The study showed that cold stress $\left(12 / 6^{\circ} \mathrm{C}\right.$ day/night $)$ did not largely reduce soybean emergence. A short-term 3-day stress, inflicted immediately after sowing and also after 3 and 6 days after sowing, reduced emergence by $6-10 \%$ on average. A longer 9 -day cold stress did delay emergence by 9 days, but the number of germinated seeds was only $5 \%$ lower than in the control, which means that temperature drops of a few days were not the cause of much worse emergence. On the basis of research conducted in Switzerland [12], it was found that low temperature after sowing soybean may cause prolonged germination, rotting of some seeds, while the emergency of the remaining seeds is slowed down and delayed. In our research, the cold stress caused a prolonged germination and delayed emergence, and a few percent reduction in emergence could have been caused by some of the seeds rotting. However, it should be noted that varietal variation in germination may reflect the capacity of particular lot of seeds used for this study. On the other hand, earlier sowing of soybeans can be beneficial in terms of extending the growing season. Hinson and Hartwig [32] found that soybean seeds can germinate at temperatures from 
5 to $40{ }^{\circ} \mathrm{C}$. The study showed that a drop in temperature to $6{ }^{\circ} \mathrm{C}$ at night for a period of 9 days, inhibited plant emergence, but when the temperature rose, the plants emerged evenly, which means that they had not been damaged. According to certain authors, spring chill for soybean is not so harmful as heavy rains, which especially on heavy soils, cause soil crusting and consequently problems with emergence and optimal plant density [33] and weed infestation in the early growth stages of soybean [34-36].

The study showed that cold stress had a positive effect on soybean yield. After a short overcooling of germinating seeds (treatments B and C) only two cultivars showed a significant increase in yield, but after a longer chilling of seeds (treatment D), the yield was significantly higher in 12 cultivars, and in the remaining four cultivars such a tendency was recorded. This means that temperature drops immediately after sowing, even for a longer time, do not limit plant growth and development but, on the contrary, they increase plant vitality and have a positive effect on yield. Many authors consider early sowing of soybean as a key agronomic element in achieving high seed yield. Egli and Cornelius [37] showed that in the southern states of the USA, earlier sowing of soybean causes a significant increase in yield, while delaying it until the end of May and the beginning of June significantly reduces it. According to the authors, an earlier sowing date is associated with earlier flowering of plants, which allows to avoid late summer drought and reduces disease and pest pressure. However, early sowing must be conditioned by favorable field conditions (rainfall, temperature). A study by Pedersen and Lauer [38] showed that an earlier sowing date for soybean resulted in a higher number of pods and seeds and consequently a higher yield than a later date. According to Egli and Bruening [39], late sowing of soybean shortens plant vegetation due to the complex effects of temperature and photoperiod. This can result in shorter plants, fewer nodes, lower vegetative weight at the beginning of seed filling and reduced flowering. Documented increases in soybean yield associated with earlier sowing are also presented by other authors [40-42]. Meyer and Badaruddin [43] found that early sowing should be a prudent management practice leading to increased soybean yields, especially in cooler regions, because it can expose the soybean to spring frosts, in which resow may be necessary. Therefore, in the northern U.S. states, where spring starts later and there are earlier fall frosts that limit the growing season, soybean producers are more cautious about the optimal seeding date that also minimizes the risks associated with cold, wet soils and seed pathogens [44]. In the USA, soybeans are sown immediately after maize, when soil temperatures reach $10{ }^{\circ} \mathrm{C}$, which, in the northern part of this country, generally falls at the end of May [40]. On the other hand, sowing in late spring is associated with lower water resources in the soil and poorer seed germination, or heavy rains that encrust the soil [45]. Therefore, in certain years, unfavorable spring conditions can reduce plant density and consequently yield, regardless of the sowing date [44]. De Bruin and Pedersen [40] report that in cool spring climates, soybean growers can increase yields by sowing soybeans 1 to 2 weeks earlier than the recommended optimum dates.

Soybean cultivars respond unevenly to seed overcooling associated with earlier sowing. In the conducted research, early and very early cultivars responded best to prolonged overcooling of seeds, while a slightly smaller yield increase was recorded in semi-late and late cultivars. In a study of Mourtzinis et al [33], the highest seed yield was obtained from early sowing of cultivars belonging to earliness group MG2, while cultivars from groups MG0.6-1.2 responded poorly to sowing date. Salmeron et al [46] found that combining early sowing with cultivars from the MG4 and MG5 groups gave favorable yield results in the US Midsouth. The yield reduction associated with later sowing (late May/early June) compared to earlier sowing (April/early May) was 6-18\% depending on the cultivar. The selection of the cultivar to be grown is therefore crucial, as the response to environmental factors, especially stresses, can vary even within a single earliness group, as shown in the study. For example, in the late cultivars Madlen and Lissabon, the increase in seed yield after prolonged cold stress was 34.3 and $10.5 \%$, respectively, while in the early cultivars Annushka and Paradis, it was 41.7 and $15.5 \%$, respectively. 
The results obtained show that cold stress applied after sowing of soybean did not significantly affect the quality of seed yield, indicating a larger influence of habitat and weather factors during the growing season on this trait. Research conducted under field conditions showed that earlier sowing of soybean (in April) resulted in higher crude fat, oleic acid, and sucrose content in seeds, while later sowing (in June) resulted in higher protein and linolenic acid contents [1]. However, according to the authors, these changes may have been due to variability in environmental factors during the growing season, primarily drought and high temperatures. In particular, the increase in sugar content may have been related to the response to environmental stress. Kane et al [47] showed that delayed soybean sowing increased protein and linolenic acid content and decreased crude fat and oleic acid content, whereas it did not affect palmitic, stearic and linoleic acid levels. In contrast, higher temperatures during seed filling associated with earlier sowing of soybean were strongly correlated with increased crude fat and oleic acid content and decreased linolenic acid levels in the soybean cultivars tested. Additionally, Kołodziej and Pisulewska [24] found that the yield and fat content of soybean seeds depended on the weather conditions during the growing season, especially on air temperature. High thermal requirements of this species were demonstrated, among others, by the Aldana cultivar, in which the value of the correlation coefficient of seed yield with the maximum temperature amplitude was 0.999 at the significance level $p=0.01$, and with the minimum temperature 0.788 at the significance level $p=0.05$. Air temperature did not significantly affect the fat content in seeds of the cultivars studied. A significant effect of high temperature on fat accumulation and a decrease in protein content in soybean seeds was demonstrated by other authors [48,49]. In turn, Hou et al [19] found that the fat content in the seed and the ratio of saturated to unsaturated acids are more affected by the extreme minimum daily temperatures during September seed filling than by the average or maximum air temperature and the geographical location.

In the study conducted, the chemical composition of soybean seeds significantly depended on the genetic factor (cultivar), which confirms the results of other authors. Piper and Boote [50] showed variation in nutrient content in 20 soybean cultivars, with protein content significantly dependent only on cultivar, while fat content was equally affected by cultivar and temperature related to latitude. Kozak et al [51] found, however, that the chemical composition of soybean seeds depended to the greatest extent on climatic conditions, followed by the varietal factor. In a study of Biel et al [52], the varietal factor had a significant effect on fat and ash content (the Merlin cultivar contained more fat than Aldana). In turn, Nascimento et al [53] showed a coefficient of variation (CV) of $6.9 \%$ for fat content in 15 soybean genotypes. They also indicated a strong interaction of genotype with habitat conditions. A significant interaction of temperature and cultivar on seed yield and the contents of protein, fat, fatty acid, and carbohydrates (raffinose and stachyose), was also demonstrated by Alsajri et al [54].

\section{Conclusions}

Sowing date and soybean cultivar can have a major impact on the quantity and quality of the soybean seed yield, and can therefore increase or decrease overall farm profitability. Low temperatures during soybean sowing $\left(6^{\circ} \mathrm{C}\right.$ at night) lasting for a period of 9 days delayed, but did not significantly reduce plant emergence, but in contrast, increased the yields of almost all the soybean cultivars studied. Spring cold stress, on the other hand, did not significantly affect the chemical composition of seeds. These results indicate that acceleration of soybean sowing by 1-2 weeks, depending on the region and field conditions (temperature, precipitation), may bring measurable benefits related to higher soybean yield, which may be of great importance in terms of soybean cultivation management. It should also be noted that other factors influencing germination and initial plant growth, such as weed competition, pest infestation or disease, should be considered when facing soybean emergence problems. 
The research carried out comparing 16 soybean cultivars under controlled and partially controlled conditions is of great diagnostic importance but, on the other hand, we are aware that the results obtained cannot be validated for field conditions. Therefore, in order to provide more accurate recommendations to a wider range of producers, environmental studies in different points of Poland are needed to capture the environmental variability in important soybean production areas in this country.

Author Contributions: Conceptualization, M.S.; methodology, M.S., K.C. and A.S.-W.; investigation, A.S.-W., M.S., K.C. and E.B.; data curation, M.S., A.S.-W. and K.C., validation, A.K. and E.B.; writing—original draft preparation M.S.; writing—review and editing, M.S., A.K., K.C. and A.S.-W.; visualization M.S. and K.C.; supervision, M.S.; funding acquisition, M.S. and A.K. All authors have read and agreed to the published version of the manuscript.

Funding: The studies have been supported by the Polish Ministry of Science and Higher Education within the statutory activity of the Institute of Soil Science and Plant Cultivation-State Research Institute, task 1.23 Biological and agrotechnical aspects of soybean (Glycine max (L.) Merr.) reaction to cold stress.

Conflicts of Interest: The authors declare no conflict of interest. The funders had no role in the design of the study; in the collection, analyses, or interpretation of data; in the writing of the manuscript, or in the decision to publish the results.

\section{Appendix A}

Table A1. Two-ways analysis of variation (ANOVA) done for seeds yield.

\begin{tabular}{cccccc}
\hline Factors & $\begin{array}{c}\text { Sum of } \\
\text { Squares }\end{array}$ & df & $\begin{array}{c}\text { Mean } \\
\text { Square }\end{array}$ & F-Ratio & $\boldsymbol{p}$-Value \\
\hline Stress regime & 2100.69 & 4 & 525.17 & 54.98 & 0.000 \\
Variety & 9887.46 & 15 & 659.16 & 69.00 & 0.000 \\
Interaction & 963.02 & 60 & 16.05 & 1.68 & 0.005 \\
\hline
\end{tabular}

\section{References}

1. Bellaloui, N.; Bruns, H.A.; Abbas, H.K.; Mengistu, A.; Fisher, D.K.; Reddy, K.N. Agricultural practices altered soybean seed protein, oil, fatty acids, sugars, and minerals in the Midsouth USA. Front. Plant Sci. 2015, 6, 1-14. [CrossRef] [PubMed]

2. SOYSTATS 2020. Available online: http:// soystats.com/ (accessed on 22 January 2021).

3. Krishnan, H.B. Engineering soybean for enhanced sulfur amino acid content. Crop Sci. 2005, 45, 454-461. [CrossRef]

4. Borawska, J.; Darewicz, M.; Iwaniak, A.; Minkiewicz, P. Biologically active peptides derived from food proteins as prevention factors for selected diet-related diseases. Bromat. Chem. Toksykol. 2014, 47, 230-236. (In Polish)

5. Ghani, M.; Kulkarni, K.P.; Song, J.T.; Shannon, J.G.; Lee, L.J. Soybean sprouts: A review of nutrient composition, health benefits and genetic variation. Plant Breed. Biotech. 2016, 4, 398-412. [CrossRef]

6. Kotecki, A. (Ed.) Plant Cultivation, Volume 3; Uniwersytet Przyrodniczy we Wrocławiu: Wrocław, Poland, 2020; pp. 161-206. (In Polish)

7. Badaruddin, M.; Meyer, D.W. Grain legume effects on soil nitrogen, grain yield, and nitrogen nutrition of wheat. Crop Sci. 1994, 34, 1304-1309. [CrossRef]

8. Martyniuk, S. Scientific and practical aspects of legume symbiosis with nodule bacteria. Pol. J. Agr. 2012, 9, 17-21. (In Polish)

9. FAOSTAT 2020. Available online: http://www.fao.org/faostat/en/-data/QC (accessed on 12 January 2021).

10. Kozyra, J.; Doroszewski, A.; Nieróbca, A. Climate changes and their expected impact on agriculture in Poland. Studia $i$ Raporty IUNG-PIB 2009, 14, 243-257. (In Polish)

11. Câmara, G.M.S.; Sediyama, T.; Dourado-Neto, D.; Bernardes, M.S. Influence of photoperiod and air temperature on the growth, flowering and maturation of soybean (Glycine max (L.) Merrill). Sci. Agric. 1997, 54, 149-154. [CrossRef]

12. Gass, T.; Schori, A.; Fossati, A.; Soldati, A.; Stamp, P. Cold tolerance of soybean (Glycine max (L.) Merr.) during the reproductive phase. Eur. J. Agron. 1996, 5, 71-88. [CrossRef]

13. Gaynor, L.G.; Lawn, R.J.; James, A.T. Agronomic studies on irrigated soybean in southern New South Wales. I. Phenological adaptation of genotypes to sowing date. Crop Pasture Sci. 2011, 62, 1056-1066. [CrossRef]

14. Cai, Y.; Chen, L.; Zhang, Y.; Yuan, S.; Su, Q.; Sun, S.; Wu, C.; Yao, W.; Han, T.; Hou, W. Target base editing in soybean using a modified CRISPR/Cas9 system. Plant Biotechnol. J. 2020, 18, 1996-1998. [CrossRef] 
15. Ohnishi, S.; Miyoshi, T.; Shirai, S. Low temperature stress at different flower developmental stages affects pollen development, pollination, and pod set in soybean. Environ. Exp. Bot. 2010, 69, 56-62. [CrossRef]

16. Łykowski, B. Climatic Conditions for the Development and Yielding of Soybean in Poland; Rozpr. Nauk. i Monogr. SGGW Warszawa: Warszawa, Poland, 1984; pp. 5-84.

17. Gao, C. The future of CRISPR technologies agriculture. Nat. Rev. Mol. Cell Biol. 2018, 19, 275-276. [CrossRef]

18. Zhang, L.; Liu, W.; Tsegaw, M.; Xu, X.; Qi, Y.; Sapey, E.; Liu, L.; Wu, T.; Sun, S.; Han, T. Principles and practices of the photo-thermal adaptability improvement in soybean. J. Integr. Agric. 2020, 19, 295-310. [CrossRef]

19. Hou, G.; Ablett, G.R.; Pauls, K.P.; Rajcan, I. Environmental effects on fatty acid levels in soybean seed oil. J. Am. Oil Chem. Soc. 2006, 83, 759-763. [CrossRef]

20. Thomashow, M.F. Plant cold acclimation: Freezing tolerance genes and regulatory mechanisms. Annu. Rev. Plant Physiol. Plant Mol. Biol. 1999, 50, 571-599. [CrossRef]

21. Livingston, D.P.; Hincha, D.K.; Heyer, A.G. Fructan and its relationship to abiotic stress tolerance in plants. Cell. Mol. Life Sci. 2009, 66, 2007-2023. [CrossRef] [PubMed]

22. Yuanyuan, M.; Yali, Z.; Jiang, L.; Hongbo, S. Roles of plant soluble sugars and their responses to plant cold stress. Afr. J. Biotechnol. 2009, 8, 2004-2010. [CrossRef]

23. Michałek, S.; Borowski, E. Yielding, oil, fatty acids and protein content in the seeds of polish soybean cultivars under drought conditions. Acta Agroph. 2006, 8, 459-471.

24. Kołodziej, J.; Pisulewska, E. Influence of meteorological factors on the yield of seeds and fat as well as fat content in seeds of two soybean cultivars. Rośliny Oleiste 2000, XXI, 759-773. (In Polish)

25. Anioł, A.; Bielecki, S.; Twardowski, T. Genetically modified organisms-Opportunities and threats for Poland. Nauka 2008, 1, 63-84. (In Polish)

26. EU Common Catalogue of Varieties of Agricultural Plant Species. 2020. Consolidated Version, 20 September 2019. Available online: https:/ / ec.europa.eu/food/sites/food/files/plant/docs/plant-variety-catalogues_agricultural-plant-species.pdf (accessed on 22 January 2021).

27. Kjeldahl, J.A. New Method for the Determination of Nitrogen in Organic Matter. Z. Anal. Chem. 1883, 22, 366-382. [CrossRef]

28. Soxhlet, F. The weight analytic determination of milk fat. Polytech. J. 1879, 232, 461-465.

29. Official Methods of Analysis of the AOAC. Wyd. XX; Association of Official Analytical Chemists: Rockville, MD, USA, 2016.

30. Nogala-Kałucka, M. (Ed.) Analiza Żywności. Wybrane Metody Oznaczeń Jakościowych i Ilościowych Składników Żywności; Wyd. UP: Poznań, Poland, 2016. (In Polish)

31. Jones, D.B. Factors for Converting Percentages of Nitrogen in Foods and Feed into Percentages of Proteins; Circular, 1941, No. 183 (Original Version, 1931); United States Department of Agriculture: Washington, DC, USA, 1931.

32. Hinson, K.; Hartwig, E.E. Soybean Production in the Tropics; FAO Plant Production and Protection Paper; FAO: Roma, Italy, 1982; Volume 4, pp. 2-12.

33. Mourtzinis, S.; Gaspar, A.P.; Naeve, S.L.; Conley, S.P. Planting date, maturity, and temperature effects on soybean seed yield and composition. Agron. J. 2017, 109, 2040-2049. [CrossRef]

34. Vollmann, J.; Wagentristl, H.; Hartl, W. The effects of simulated weed pressure on early maturity soybeans. Eur. J. Agron. 2010, 32, 243-248. [CrossRef]

35. Gawęda, D.; Haliniarz, M.; Bronowicka-Mielniczuk, U.; Łukasz, J. Weed infestation and health of the soybean crop depending on cropping system and tillage system. Agriculture 2020, 10, 208. [CrossRef]

36. Biszczak, W.; Różyło, K.; Kraska, P. Yielding parameters, nutritional value of soybean seed and weed infestation in relay-strip intercropping system with buckwheat. Acta Agric. Scand. B Soil Plant Sci. 2020, 70, 640-647. [CrossRef]

37. Egli, D.B.; Cornelius, P.L. A regional analysis of the response of soybean yield to planting date. J. Agron. 2009, 101, 330-335. [CrossRef]

38. Pedersen, P.; Lauer, J.G. Response of soybean yield components to management system and planting date. J. Agron. 2004, 96, 1372-1381. [CrossRef]

39. Egli, D.B.; Bruening, W.P. Potential of early-maturing soybean cultivars in late plantings. J. Agron. 2000, 92, 532-537. [CrossRef]

40. De Bruin, J.L.; Pedersen, P. Soybean seed yield response to planting date and seeding rate in the upper Midwest. J. Agron. 2008, 100, 696-703. [CrossRef]

41. Gaspar, A.P.; Conley, S.P. Responses of canopy reflectance, light interception, and soybean seed yield to replanting suboptimal stands. Crop Sci. 2015, 55, 377-385. [CrossRef]

42. Marburger, D.A.; Smith, D.L.; Conley, S.P. Revisiting planting date and cultivar effects on soybean sudden death syndrome development and yield loss. Plant Dis. 2016, 100, 2152-2157. [CrossRef] [PubMed]

43. Meyer, D.W.; Badaruddin, M. Frost tolerance of ten seedling legume species at four growth stages. Crop Sci. 2001, 41, 1838-1842. [CrossRef]

44. Murillo-Williams, A.; Pedersen, P. Early incidence of soybean seedling pathogens in Iowa. J. Agron. 2008, 100, 1481-1487. [CrossRef]

45. Helms, T.C.; Deckard, E.; Goos, R.J.; Enz, J.W. Soybean seedling emergence influenced by days of soil water stress and soil temperature. J. Agron. 1996, 88, 657-661. [CrossRef] 
46. Salmeron, M.; Gbur, E.E.; Bourland, F.M.; Buehring, N.W.; Earnest, L.; Fritschi, F.B.; Golden, B.R.; Hathcoat, D.; Lofton, J.; Miller, T.D.; et al. Soybean maturity group choices for early and late plantings in the Midsouth. J. Agron. 2014, 106, 1893-1901. [CrossRef]

47. Kane, M.V.; Steele, C.C.; Grabau, L.J.; MacKown, C.T.; Hildebrand, D.F. Early-maturing soybean cropping system: III. Protein and oil contents and oil composition. J. Agron. 1997, 89, 464-469. [CrossRef]

48. Nakagawa, A.C.S.; Ario, N.; Tomita, Y.; Tanaka, S.; Murayama, N.; Mizuta, C.; Iwaya-Inoue, M.; Ishibashi, Y. High temperature during soybean seed development differentially alters lipid and protein metabolism. Plant Prod. Sci. 2020, 23, 504-512. [CrossRef]

49. Rotundo, J.L.; Miller-Garvin, J.E.; Naeve, S.L. Regional and temporal variation in soybean seed protein and oil across the United States. Crop Sci. 2016, 56, 797-808. [CrossRef]

50. Piper, E.L.; Boote, K.J. Temperature and cultivar effects on soybean seed oil and protein concentrations. J. Am. Oil Chem. Soc. 1999, 76, 1233-1241. [CrossRef]

51. Kozak, M.; Malarz, W.; Kotecki, A.; Černý, I.; Serafin-Andrzejewska, M. Influence of different amounts of sowing and Asahi SL biostimulator on the chemical composition of seeds and post-harvest residues of soybean. Rośliny Oleiste 2008, 29, 217-230. (In Polish)

52. Biel, W.; Gawęda, D.; Łysoń, E.; Hury, G. The influence of genetic and agrotechnical factors on the nutritional value of soybean. Acta Agroph. 2017, 24, 395-404. (In Polish)

53. Nascimento, M.; Finoto, E.L.; Sediyama, T.; Cruz, C.D. Adaptability and stability of soybean in terms of oil and protein content. Crop Breed. Appl. Biotechnol. 2010, 10, 48-54. [CrossRef]

54. Alsajri, F.A.; Wijewardana, C.; Irby, J.T.; Bellaloui, N.; Krutz, L.J.; Golden, B.; Gao, W.; Reddy, K.R. Developing functional relationships between temperature and soybean yield and seed quality. J. Agron. 2020, 112, 194-204. [CrossRef] 